\title{
Estrategias familiares, práctica jurídica y comunidad de memoria. Los descendientes de Tito Alonso Atauchi y Viracocha Inca en Charcas, Siglos XVI-XVIII
}

\section{Family strategies, legal practice and community of memory. The descendants of Tito Alonso Atauchi and Viracocha Inca in Charcas, XVI-XVIII Centuries}

\author{
Nelson Castro Flores ${ }^{1}$ https//orcid.org/0000-0001-5539-1991 \\ ${ }^{1}$ Universidad Viña del Mar. Viña del Mar, CHILE. Email: ncastro@uvm.cl
}

\begin{abstract}
Resumen
Desde la segunda mitad del siglo XVIII, entre algunos miembros de la burocracia imperial, se experimentó un fuerte recelo hacia la nobleza indígena y sus lugares de memoria. Estos fueron visualizados como una fuente de alteración nociva para el cuerpo político. La rebelión general de 1781 no hizo más que acrecentar los temores hacia las élites indígenas, a pesar de que la mayor parte de estas se mantuvieron fieles al gobierno colonial. En diversas coyunturas, descendientes de los señores naturales presentaron un conjunto de pedimentos, memoriales y autos, muchos de ellos originados en los siglos XVI y XVII, para adaptarse a los cambios que se producían a nivel de la administración colonial. Esta estrategia siguió siendo utilizada, con posterioridad a la rebelión de 1781, y ofreció a las familias de la nobleza indígena un soporte imprescindible para su memoria cultural, en la medida que les permitió conservar líneas directrices e imágenes identitarias.
\end{abstract}

Palabras claves: nobleza indígena, Charcas colonial, memoria cultural, ideología nobiliaria.

\begin{abstract}
From the second half of the XVIII century, a strong apprehension feeling rose among some members of the imperial bureaucracy towards the indigenous nobility and their places of memory. They were visualized as a source of noxious disturbance for the political body. The 1781 general revolt just increased the fear towards indigenous elites, even though they remained loyal to the colonial government. At several junctures, descendants of the natural lords submitted a set of petitions, memorials and autos, many of which were originated in the XVI and XVII centuries, in order to adapt themselves to the changes of that time in the colonial administration. This strategy was repeatedly used after the 1781 revolt and provided the indigenous nobility's families a support for their cultural memory, to the extent that they were allowed to preserve guidelines and identity images.
\end{abstract}

Keywords: Indigenous nobility, colonial Charcas, cultural memory, nobiliary ideology.

Recibido: 29 noviembre 2016. Aceptado: 3 julio 2017 


\section{Introducción}

En 1696, don Lope de Sierra Osorio y el fiscal del Consejo de Indias consideraron que debía ser atendido el pedimento de don Juan Núñez de Vela, racionero de la catedral de Arequipa, en orden a reconocer "la límpisima y noble sangre de los indios" en todos aquellos cargos en que se exigía limpieza de sangre (Konetzke, 1962, III, p. 64). Al año siguiente, se despachó una real cédula en la que se reconoció, a los indios principales y sus descendientes, el goce de "todas las preeminencias y honores, así en lo eclesiástico como en lo secular, que se acostumbra a conferir a los nobles hijoshidalgos de Castilla", bajo la consideración que sus ascendientes eran nobles ya en tiempos de la gentilidad (Konetzke, 1962, III, p. 67). O'Phelan ha señalado que, en la segunda década del siglo XVIII, estas disposiciones desataron "entre la elite indígena la 'fiebre' por las probanzas de nobleza” (1999, p. 264). La misma situación se observa en la década de 1680 tras la publicación de la Recopilación de Leyes de Indias, aunque en una menor escala. Las disposiciones correspondientes a los indios principales entregaron un buen argumento para legitimar estrategias familiares de usos del pasado, a través de la configuración de relatos sancionados jurídicamente, en los que se amparó los privilegios de quienes se concebían a sí mismos como provistos de derechos de sangre (Castro e Hidalgo, 2008; Hidalgo y Castro, 2014). Pero la cédula de 1697, y la reiteración de su tenor en la década de 1720, tuvo mayor impacto por cuanto homologó a la denominada nobleza indígena con los hidalgos castellanos, posibilitando nuevas iniciativas. Al respecto Carrillo (2006) ha demostrado que a los nobles indígenas limeños les permitió ampliar su espacio de representación política local, postulándose como "cabeza de la nación índica" para obtener privilegios reales. Por su parte, Zighelboim (2010, p. 11) ha señalado que la cédula de 1697 se convirtió en "una causa reivindicatoria de los mestizos y los indios de elite en un proceso incipiente de politización de sus demandas colectivas", además de alentar el desarrollo de estrategias personales y colectivas como lo demuestra el análisis de la documentación correspondiente a Carlos Inga Bustamante. En la misma perspectiva, para la década de 1730 , se ha observado el desplazamiento de las memorias per- sonales y familiares de la nobleza indígena limeña hacia la configuración de un relato colectivo en el que se entretejieron los recuerdos genealógicos de linajes regionales (Glave, 2011).

En este contexto algunos nobles indígenas presentaron memoriales a la audiencia de La Plata para que se les reconocieran los privilegios otrora concedidos a los descendientes de incas. Pero lo hacían amparados en una asentada práctica jurídica celosamente resguardada en documentación proveniente del siglo XVI. Precisamente, más allá de las novedades impuestas por las cédulas de 1697, o las disposiciones de 1725 , esta documentación evidencia que muchas familias indígenas sostuvieron el reconocimiento de su nobleza apoyadas en un corpus documental configurado desde la segunda mitad del siglo XVI hasta fines del siglo XVIII. Aunque se puede sostener una cierta continuidad en las estrategias familiares, sin embargo, no debe desatenderse la relación que estas tuvieron con los cambios políticos y administrativos que afectaron a la administración colonial (Jurado, 2014). Asimismo, no deben descuidarse los efectos que las decisiones de las audiencias tuvieron en las prácticas de las familias de notables indígenas, que Morrone ha denominado como "enroque estratégico" (Morrone, 2013).

En este trabajo el propósito es analizar el modo en que familias que pretendían descender de Tito Alonso Atauchi o de Viracocha Inca vincularon su memoria familiar a una red de sociabilidad, aunque de un modo que es más propio de la fabulación que a de la memoria en sentido mnemotécnico (Amphoux y Ducret, 1985, p. 199). En este sentido, las diversas filiaciones y testimonios presentados para respaldar su descendencia del linaje real de los Incas se estructuraron como un relato y no constituyeron un mero recuerdo evocado en el contexto de un juicio. Las redes de sociabilidad, que eran la expresión de intereses y alianzas, permitieron imponer en los espacios locales una "voz pública y común opinión" que redundó en el reconocimiento del prestigio y la nobleza alegado por más de algún pretendiente, constituyendo de esta manera una "comunidad de memoria” (Burke, 2000). Además, los relatos sancionados jurídicamente ofrecieron un soporte para la "memoria cultural", en la medida en que conser- 
vó "líneas directrices e imágenes identitarias" que podían ser utilizadas por los miembros de un linaje (Marchal, 2001).

Este trabajo se apoya en un extenso corpus documental que se ha recopilado en estadías de investigación en el Archivo y Biblioteca Nacionales de Bolivia, Archivo General de Indias, Archivo Eclesiástico de La Paz y Archivo General de la Nación Argentina. Particularmente, estos dos últimos archivos permitieron acceder a documentación presentada, en la segunda mitad del siglo XVIII, por el presbítero Nicolás Tadeo de Miranda, en un período caracterizado por el recelo frente a la denominada nobleza indígena. Esto ha llevado a delimitar, en un primer apartado, la configuración cultural de la nobleza en Charcas colonial, enfatizando su temprana apropiación de la ideología nobiliaria y de la práctica jurídica de las probanzas de hidalguía (Puente, 2017), así como de los intersticios que abrió el debate sobre el señorío natural. Honores $(2007,2010)$ ha señalado la activa participación de los sujetos andinos en la apropiación de la tradición jurídica castellana, principalmente a través del reclamo en las audiencias, cuyas salas se transformaron en espacios de diálogos y maniobras, a pesar de las restricciones impuestas por el virrey Francisco de Toledo. A la larga, esto permitió la construcción de lo que Honores denominó una "cultura jurídica colonial", caracterizada por la polifonía legal, en la que se incorporaron los argumentos elaborados por las élites indígenas y los letrados que las representaron. Esto se evidencia en memoriales y probanzas presentadas por algunas familias de notables indígenas en Charcas desde la segunda mitad del siglo XVI hasta fines del siglo XVIII.

No obstante, en la segunda mitad del siglo XVIII, los descendientes de la nobleza indígena tuvieron que maniobrar en un escenario aparentemente menos propicio para sus pretensiones. Esto último se describe en el segundo apartado de este artículo, enfatizándose los esfuerzos de los notables indígenas de Charcas por presentarse como leales vasallos de la monarquía durante la rebelión general de 1781 . Incluso resignificaron la medalla que les otorgó la audiencia de La Plata como reconocimiento de su lealtad, como expresión de pertenencia a una orden nobiliaria.
La delimitación de estos aspectos permite, en un último apartado, analizar la documentación presentada por el presbítero Nicolás Tadeo de Miranda como parte de una estrategia familiar elaborada, en distintas coyunturas administrativas, por sus ascendientes desde fines del siglo XVI hasta las últimas décadas del siglo XVIII. Esto permite dimensionar el archivo familiar, recompuesto en sucesivas peticiones, como soporte de la memoria familiar y del sentido de pertenencia estamental. Pero no debe descuidarse que esta memoria familiar fue producto de selecciones, reinvenciones y resignificaciones producidas, en diversos momentos, por los ascendientes de la familia de Miranda. No se trata de un caso excepcional, como lo demuestra el estudio de Espinosa (2015) sobre Alonso Florencia Inca en Quito, o el de Quispe-Agnoli (2016) sobre María Joaquina Inca en México.

\section{La configuración cultural de la no- bleza indígena en Charcas colonial}

Desde la segunda mitad del siglo XVI, los miembros de los principales linajes indígenas de Charcas colonial solicitaron para sí, sus familias y descendientes el reconocimiento y trato como indios nobles. Algunos contaban con las mercedes y reconocimientos nobiliarios concedidos tempranamente por la Corona, como fue el caso de las familias que se reclamaban descendientes de don Alonso Tito Atauchi, a quien en 1544 le fue concedido un escudo de armas -como aconteció con miembros de las élites indígenas en el siglo XVI (Gil-Loyzaga, 2012)-, o de los incas principales e incluso de los grandes mallku (Arze y Medinacelli, 1991; Gisbert, 2004, pp. 157-162; Escobari, 2001, pp. 107-136). A estas familias las prerrogativas les fueron concedidas documentalmente, por lo que resguardaron con celo dichos papeles y los esgrimieron en más de alguna ocasión para defender la nobleza y el honor de sus casas y exigir las honras y franquicias concedidas a sus ancestros. Estos documentos permiten al historiador pesquisar un entramado de prácticas y significados que delimitaron la configuración cultural (Grimson, 2011) que compartieron los miembros de las élites indígenas del área 
de Charcas entre el siglo XVI hasta fines del siglo XVIII. ${ }^{1}$

La práctica jurídica abrió un campo de posibilidad a los notables indígenas, y también a los indios del común, proveyéndolos de instrumentos para pleitear ante las jurisdicciones coloniales (Cordero, 2017; Espinoza, 2015; Honores, 2010; Rojas, 2010; Yannakakis, 2013). Hacia 1588, el cura Bartolomé Álvarez, un antiguo doctrinero de Aullagas, señalaba que algunos indios habían adquirido libros como la Pratica ciuil y criminal y instrvccion de escrivanos (1563), de Gabriel Monterroso y Alvarado, o Las Siete Partidas de Alfonso X, con el propósito de saber cómo "poner un pleito y hacer una petición para mover una acusación” (Álvarez, 1998, p. 268 [1588]). El libro de Gabriel Monterroso fue utilizado en la preparación de los escribanos, aunque la mayoría aprendía el oficio en la práctica (Burns, 2005); además, como se señala en Álvarez, el manual fue ampliamente comercializado en el virreinato peruano (Jurado, 2014). Precisamente, el tratado sexto del libro de Gabriel Monterroso contenía una sección en la que se describía la práctica de las probanzas de hidalguía, que se consideraba un negocio importante, "pues los hombres hijos dalgos, decienden de nobleza, y esfuerço y valentia, aunq otros son de priuilegio y merced del Rey" (Monterroso, 1591, pp. 108v-109r [1563]). En estos pleitos, un hidalgo se jugaba la honra y libertad de su persona y hacienda, de ahí la importancia que en la Península adquirieron las cartas ejecutorias de hidalguía (Ruiz, 2006). El procedimiento castellano establecía varias maneras de litigar, en las audiencias reales, las probanzas de hidalguía. En Valladolid y Granada había alcaldes que juzgaban en primera instancia y sus fallos se apelaban a las audiencias reales. Los testimonios eran recogidos por escribanos, quienes incluso concurrían al lugar de procedencia del interesado,

1 El concepto de configuración cultural, sugerido por Grimson, se aleja de los usos funcionalistas que aquel ha recibido entre algunos investigadores. De acuerdo con Grimson (2011, pp. 171-194), en una configuración cultural se deben distinguir cuatro elementos constitutivos: las configuraciones como campos de posibilidad; las representaciones, prácticas e instituciones posibles; pero también representaciones, prácticas e instituciones imposibles; además de representaciones, prácticas e instituciones hegemónicas. en el caso de que sus testigos estuviesen impedidos, pero también se hacía registro y tomaba declaraciones a testigos adversos. Una segunda modalidad la constituía la probanza ad perpetuam rei memoriam que se producía sin que mediase alguna solicitud en específico, pero que un interesado juzgaba necesario probar y resguardar bajo el temor de "que los testigos con quien lo podria prouar, se moririan" (Monterroso, 1591, pp. 109 r [1563]). La información original se guardaba en el archivo de la audiencia -registrándose la fecha, cómo se había realizado la probanza, los nombres y número de testigos-, y se entregaba una fe de la probanza al interesado. Además, había dos maneras más para probar la hidalguía, pero en un contexto judicial, ya sea por deudas o por algún otro delito, y que tenían por propósito resguardar los fueros del hidalgo inculpado.

No obstante, las probanzas de hidalguía se sometían a un interrogatorio cuyas preguntas versaban, entre otras, sobre el conocimiento que el testigo tenía del litigante o de sus antecesores; si sabía si estos eran "hombres notorios hijos dalgo, y de solar conocido, y de deuengar quinientos sueldos según fuero de España, y en tal possesión y reputacion estuuiero y han estado, y han sido auidos y tenidos, y comunmente reputados" (Monterroso, 1591, pp. 109 v-110 r [1563]); además, el testigo debía señalar si en un lapso de veinte o hasta cien años o más, los antecesores habían estado en posesión de notorios hidalgos de solar conocido, guardándoseles "todas las essenciones, libertades, preeminencias que suelen y acostumbran guardar a los hombres notorios hijos dalgo destos Reynos, y assi lo han visto los testigos en sus tiempos, y lo oyeron dezir a sus mayores y mas ancianos, que dezian que assi lo auian visto y oydo dezir a los suyos" (Monterroso, 1591, pp. 109110r [1563]).

La probanza de hidalguía recogía la "pública voz y fama, y común opinión" que circulaba entre vecinos de una localidad. La fama publica conservaba un mayor crédito que los testimonios directos porque esta estaba garantizada por la notorietas, y el derecho consuetudinario medieval disponía que lo notorio no requería ser probado (Marchal, 2001, pp. 581). Este instrumento fue utilizado por los miembros de las familias de la nobleza indígena para legitimar 
relatos y memorias familiares, particularmente para reivindicar derechos sucesorios y prerrogativas de hidalguía. No obstante, Juan de Solórzano y Pereira, quien se desempeńó como oidor en la Audiencia de Lima, mostró recelo respecto de las probanzas de "fama, i oidas" por cuanto podían apoyar a uno u otro litigante. De acuerdo con su propia experiencia en la vista de estos pleitos, Juan de Solórzano recomendaba que, tratándose de cosas antiguas, los casos debían diferirse con los instrumentos documentales más que con las probanzas de testigos (Solórzano, 1648, p. 226).

En medio de los cuestionamientos toledanos tendientes a restar legitimidad al señorío natural (González, 2015; Merluzzi, 2008; Morong, 2013, 2016), la nobleza indígena aprovechó la retórica jurídica colonial para negociar reconocimientos y privilegios. Con anterioridad a los cuestionamientos toledanos, Juan de Matienzo, oidor de la audiencia de La Plata, había sostenido que el término de la tiranía de los incas había permitido la restitución "en el señorío de sus tierras a los reyes e señores de ellos, que son los caciques (o curacas, que ansi llaman en esta tierra a los señores) (1967, p. 15 [1567]), anteponiéndose discursivamente a la representación toledana que antes de los incas los indios vivían en behetrías. En este sentido, Juan de Matienzo planteó que debía mantenerse el dominio del cacique sobre tierras e indios; agregando que era inconveniente que los indios de un mismo repartimiento se encontrasen divididos en diferentes encomiendas, con la consecuente merma de la autoridad de los caciques. Otros contemporáneos de Juan de Matienzo intervinieron en este debate, como fue el caso del licenciado Juan Polo de Ondegardo, quien asumió roles antagónicos en la temprana administración colonial en Charcas; junto con asumir funciones burocráticas fue también un activo encomendero, hacendado, minero y comerciante (Hampe, 1985-86; Lamana, 2012; Presta, 2014, pp. 197-250). Polo de Ondegardo retomó, aunque con matices, la categoría de tiranía, para establecer el origen del señorío de los Incas, y de behetría, para comprender que en su expansión no hubo una resistencia mancomunada. Pero consideró que la sujeción de esas behetrías, que se regían cada una por leyes "conforme a ynstinto natural", permitió incorporar a indios que "eran bestias", bajo un régimen más político, del que surgieron los usos y costumbres observados en tiempo del Inca. Además, Polo de Ondegardo sostuvo que debía guardarse los fueros de los indios, considerándolos en la determinación de sus pleitos, incluso en cuestiones que sobrepasaban a la "buena policía", para no quitarles un derecho adquirido y obligarlos a sufrir leyes que desconocían y que tampoco entenderían (1916, p. 47). La intención de Polo de Ondegardo no consistía en una defensa lascasiana de los fueros y costumbres indígenas, sino que formaba parte de una propuesta que, a partir de un conocimiento exhaustivo de dichos fueros y costumbres, permitiese hacerles justicia y entender qué es lo que se debía cambiar y proveer para atraerlos a "toda buena policía” (1916, p. 48). De esta manera, la propuesta intentaba conciliar la práctica jurídica de resguardo del derecho natural, eliminando aquello que le fuere contrario, y la obligación de la Monarquía de hacer vivir, a los indios, en policía civil y cristiana, sin que para estos implicase violencia y agravio.

Las posiciones sostenidas por Juan de Matienzo y Juan Polo de Ondegardo fueron coincidentes con la Real Cédula de septiembre de 1580, en la que se expresaba la preocupación de la Corona respecto a que los indios de la provincia de los Charcas fuesen gobernados por las leyes de Castilla, "siendo diversa la república y gobierno", con lo que este se pervierte "quitándolos de la sujeción de sus caciques y curacas y señores naturales" (Enciso, 2005, p. 378). Esta Cédula ponía en cuestionamiento un aspecto central de la estrategia toledana hacia los señores naturales y también de su negativa a que los indios entablasen pleitos.

Aunque el oidor Manuel Barros criticó el yanaconazgo y defendió la libertad de los indios, sin embargo, promovió la defensa de los señores naturales -cuyo predominio restablecía la Cédula de 1580-. De acuerdo con Murra (2002, 438 [1998]), esta posición se evidenció en la escritura del Memorial de los Mallku y principales de la provincia de los Charcas (1582) y en la Memoria que presentó en nombre de don Fernando Ayavire (Platt et al., 2006, pp. 7061011). La defensa sistemática de la libertad de los indios le valió al doctor Manuel Barros la acusación del "delicto de traiçion contra su magestad", por lo 
que el Consejo de Indias ordenó su detención el 12 de julio de 1597. De acuerdo a la relación del fiscal del Consejo, en su calidad de ministro real el entonces oidor Barros no había defendido "el real señorio y el justo titulo y derecho que su magestad tiene en las Indias", más aún había amparado "a los yndios que le tenian por deçendiente de los yngas y que dezian que hauia venido a estudiar a España para defender su justiçia" ("Relaçion breue y sumaria de lo que consta y pareçe por dos proçesos que el fiscal de Yndias a presentado en el consejo contra el doctor Barros los quales no se an visto ni determinado por trazas y mańas y malos medios del dicho doctor barros y fauor que tuuo con el presidente Hernando de Vega”, AGI Quito 1, f. 56 r). El fiscal agregaba que el doctor Manuel Barros había proclamado que el rey "no tenía ni poseya las Yndias con buen titulo y que dudaua de su salvaçion y de la de los reyes de Castilla y que los verdaderos reyes y señores de las Yndias eran los yngas". ${ }^{2}$ Resultaba difícil que el letrado Manuel Barros hubiese sostenido estas posiciones; más aún, que hubiese sido partidario del señorío natural de los Incas, es una cuestión que se encuentra rebatida en el escrito que redactó para los mallku de Charcas.

En el Memorial de 1582, los mallku de Charcas se apoyaron en la noción castellana de señorío natural para legitimar su reconocimiento y cuestionar varias de las disposiciones toledanas que les habían afectado, pero, en ese mismo movimiento, reconocieron el vasallaje debido al rey. Ellos aprovecharon el intersticio que abrió el debate sobre el señorío natural, asumiendo que este lo habían gozado "antes de los Incas y después de ellos” (Platt et al., 2006, p. 832). Además, los vocablos indígenas tempranamente se correspondieron con el vocabulario nobiliario castellano, p.e., mallku como "cacique, o señor de vasallo" y su relación con maycoña o maycocaucaña, el "señorio, mando, reynado" (Bertonio, 2008, 2, p. 220 [1612]), y el uso de mayco para denotar al noble (Bertonio 2008, 1, p. 332), además de señalar la existencia de una casta noble, "Capaca vila, Mayco uila, Mayco yoca", en contraposición a una "casta de hombre hordinario" o jaqi wila (Bertonio, 2008, 1,

2 Estas acusaciones habían sido vertidas hacía ya tiempo por el licenciado Juan de Matienzo, quien a la fecha de la acusación había ya fallecido (AGI Quito 1, f. 134 r-v). p. 121 [1612]). La convicción de pertenecer a una casta o linaje (jatha) cuya sangre (wila) era noble es bastante indicativa de la apropiación que se hizo de la ideología nobiliaria castellana, particularmente en lo referido a la sangre como transmisora de virtudes y vicios (Zúñiga, 1999). Pero hay que considerar que la existencia de sistemas significantes para visualizar la autoridad y el prestigio se encontraba ampliamente desarrollada en las sociedades andinas prehispánicas, como se ha demostrado, entre otros, en los trabajos de Martínez (1995), Eeckhout y Danis (2004) y Horta (2008). Además, varios de estos distintivos fueron resignificados en la situación colonial (Cruz, 2016; Platt, 2015; Ramos, 2005). Junto con la incorporación de la ideología nobiliaria castellana, la nobleza indígena se apropió también de discursos y actitudes discriminatorias de procedencia castellana, pero que bien podían estar en conformidad con representaciones prehispánicas. Al respecto Ramos (2016, p. 85) ha relevado la importancia que tuvo para las élites indígenas el concepto de limpieza de sangre, pues les permitió incorporar nociones de pureza ancestral, rechazo de no indígenas, legitimidad de la descendencia por matrimonio, superioridad social, entre otros aspectos.

En la concepción castellana los nobles e hidalgos provenían de buen linaje, "porque se guardassen de fazer cosa porque podiessen caer en verguença. E porqǔ estos fueron escogidos de buenos logares, e co algo, que quiere dezir en lenguaje de España como bie: por esso los llamaron fijos dalgos" (Alfonso X, 1576, p. 71). Ahora bien, un hidalgo no solo debía provenir "de derecho linaje, de padre e de abuelo, fasta en el quarto grado a que llamă bisabuelos" (Alfonso X 1576, p. 71), sino que tenía la obligación de hacer crecer la honra y la hidalguía de su casa. De acuerdo con Covarrubias, la honra era la "reuerencia, cortesia que se haze a la virtud, a la potestad; algunas vezes se haze al dinero" (Covarrubias, 1611, p. 953,1), mientras que hidalguía era "la exencion, preeminencia y nobleza que goza el hidalgo" (RAE, 1734, p. 150, 2). Precisamente, sostiene Menéndez Pidal (2006), la hidalguía hereditaria concretaba el patrimonio de valores acumulado por un linaje. Esta continuidad genealógica, no exenta de contrariedades se encontraba apoyada en una "memoria histórica" que recordaba "a 
los descendientes el origen -real o fantástico- y las glorias -verdaderas o legendarias- que constituyen su patrimonio" (Menéndez Pidal, 2006, p. 21). En esto radicaba el valor que adquirieron los archivos familiares con su cúmulo de pedimentos, probanzas, cartas ejecutorias y demás documentos. Los notables indígenas también hicieron de estos archivos un lugar de memoria familiar, que complementaba, en algunos casos, el "conjunto memorial" de un linaje constituido, por ejemplo, por "sepulturas y guacas" como el analizado por Platt (2018) en la probanza de Joan de Castro y Paria.

$\mathrm{Al}$ igual que duques, condes y marqueses españoles, los mallku se presentaban como señores principales de vasallos, pero, a diferencia de aquellos, los naturales habían perdido el señorío sobre sus súbditos por las disposiciones del virrey Francisco de Toledo. En el lenguaje jurídico castellano, el virrey había desnaturado el debdo, la relación o dependencia (RAE U, 1791, p. 287, 2), que unía a los naturales con sus señores. De acuerdo con la tradición alfonsí, se trataba de un debdo de natura, es decir, una relación que expresaba un ordenamiento divino, por lo que no se podía desatar sin que existiese alguna derecha razón (Alfonso X, 1576, p. 60 v). Además, la propia tradición castellana establecía que los nobles debían ser honrados por los reyes "como aquellos con quien han de fazer su obra, guardando e honrrando asi mismos con ellos, e acrecětando su poder e su honrra” (Segunda Partida, tít. XXI, ley XXIII). De ahí entonces que, para la reparación de los agravios, los mallku hubiesen pedido que se les hiciese "mercedes como a señores y caciques principales, en franquezas y libertades, y acrecentándonos salarios conforme a la calidad y gravedad de nuestras personas, y haciéndonos mercedes como a los caballeros e hijosdalgos, como se hace en España” (Platt et al., 2006, p. 833). En cuanto vasallos del rey, y en consideración a su condición de personas de calidad ("hombre de autoridad y prendas" [Covarrubias, 1611, p. 349, 2]) y gravedad ("modestia, compostura y circunspeccion, proporcionada à la persona y estado" [RAE, 1734, p. $78,1])$, los mallku solicitaban que aquel los retribuyese con mercedes, es decir, "las gracias y las dadiuas que los Principes hazen a sus vasallos" (Covarrubias, 1611 , p. 1092, 2); particularmente en franquezas o exenciones, prerrogativas o preeminencia, inmunitas
(RAE, 1732, p. 791, 2); ninguna de las cuales tendría sentido sin libertades, es decir, sin servidumbres (Covarrubias, 1611, p. 1046, 2). Precisamente, esas franquezas y libertades se debían concretar en una serie de tratos y conductas en las que se expresaba la calidad de nobles: reserva de tasas y pechos, para hijos, nietos y hermanos de los señores principales; yanaconas para poderse sustentar como señores; aumento del salario para sustentarse cómodamente como señores; reconocimiento de los privilegios a hermanos, hijos, parientes y descendientes.

En buena medida, los mallku reclamaban el lugar que les correspondía en la escala social, pues precisamente el orden social estamental implicaba una forma de distribuir el honor social y el poder (Weber, 2014, p. 1117). En Nueva España y Nueva Castilla, las familias de los notables indígenas pudieron incorporarse a esa distribución del honor social, por cuanto la ideología habsburga suponía que la jerarquización y la estratificación entre nobles y gentes comunes correspondía a un ordenamiento natural (Garret, 2009, p. 64), pero también porque provenían de sociedades socialmente complejas y diferenciadas (Rojas, 2010), en las que sistemas rituales y atributos simbólicos habían reforzado su autoridad (Martínez, 1995). Además, no debe descuidarse que para algunos representantes del monarquismo contrarreformista, como Pedro de Rivadeneyra, el rey tenía la "responsabilidad de mantener la armonía social y de generar eficacia política mediante la preservación del orden estamental, una de cuyas fórmulas consistía en garantizar un reparto congruente del honor social" (Carrasco, 2000, p. 20).

Además, el honor condicionó la situación estamental y se expresó en la exigencia de un "modo de conducción de vida determinado" (Weber, 2014, p. 1122). Esto condujo tempranamente a las élites indígenas a la resignificación de un "ethos estamentario", que se expresó en un "deseo de distanciamiento y prestigio" (Elias, 2012, p. 135) pero que, por lo mismo, se homologó a las representaciones nobiliarias castellanas (Luque, 2004). Aunque pocos miembros de las élites indígenas participaron de la cultura de corte, no se puede descuidar que sus contenidos circularon y fueron apropiados por éstas. Bridikhina (2007, pp. 249-285) ha realizado un análisis, apo- 
yado en el enfoque de N. Elias, de los componentes de la cultura cortesana en Charcas colonial. Aunque señala que los indígenas fueron marginados de esa cultura, también indica que hubo algunos que pudieron ser reconocidos como cortesanos. Este fue el caso, entre otros tantos, del curaca don Juan Aymoro, cuya vivienda localizada en el barrio y ranchería de los Yamparaez, en Chuquisaca, parecía "casa de señor, con altos y bajos, torre, jardín, fuente y plazuela delante y muy buenos cuartos" (Ramírez del Águila, 2017, p. 109). El caso de Juan Aymoro permite dimensionar el consumo cultural de las élites indígenas en Charcas colonial en el marco de estrategias de diferenciación social (Escobari, 2001, 2011; Gisbert, 2004; Medinacelli, 2008, pp. 56-65; Medinacelli e Inch, 2010; López, 2012, pp. 151170; Choque, 2014).

En Guaman Poma es evidente el recurso al "ethos estamentario" en su afán de distinguir entre los indios de casta y los indios bajos; en su insistencia que los enlaces matrimoniales fuesen entre "yguales para que salga buena casta en este rreyno" (Guaman Poma, 1987, p. 798); y, algo no menor, en la estricta observancia de la etiqueta: aunque debía vestir como español (camisa, cuello, jubón, calzas, camegeta, capa, sombrero), sin embargo, el indio noble debía llevar el cabello hasta las orejas y no usar barbas para no parecer mestizo. Además, como todo noble, debía adornarse con espada, alabarda y otras armas, junto con usar caballos, mulas y tiana (Guaman Poma, 1987, p. 796). De acuerdo con Bertonio, la tiana o tiyana era un "Asiento de totora atada" (Bertonio, 2012, 2, p. 349, [1612]). Pero debió tratarse de una de las tantas modalidades que asumió esta silla administrativa y ceremonial. Guaman Poma señala la relación entre el material de la tiana y el grado de autoridad: oro, plata, estańo, madera y cańa, entre otras (Guaman Poma, 1987, pp. 462-467). La tiana formó parte de los emblemas de autoridad del mallku o kuraka prehispánico, pero continuó utilizándose en el período colonial, aunque en este se introdujo la vara como insignia del cargo (Martínez, 1995, p. 73). Para el virrey Francisco de Toledo, el uso de la tiana era una prerrogativa de los caciques y principales y no debía consentirse "por ninguna vía que ningún indio ora sea segunda persona o cacique de pachaca o de ayllu $u$ otro indio que tenga tiana no se asiente en ella si no fuere cacique principal que para ello tenga título o provisión mía" ("Nombramiento de don Hernando Pillohuanca como curaca de Carabuco. Arequipa, 17 de septiembre de 1575", Toledo [1986; 2, p. 114]). En el ritual de posesión de los caciques coloniales, estos eran sentados en una tiana situada en la plaza pública para que fuesen reconocidos como tales por los alcaldes y principales indígenas (Hidalgo y Castro, 2014).

Los folios que Guaman Poma dedicó al comportamiento y la etiqueta que debía ser observada por los nobles indígenas constituyen una rareza si se consideran los libros dedicados a estos temas en la literatura castellana (Carrasco, 2000), e incluso en la correspondencia privada (Baranda, 1995). No obstante, las descripciones de Guaman Poma permiten evidenciar la apropiación del ethos estamentario, por parte de las élites indígenas, y que se puede pesquisar en la documentación que estas produjeron para exigir el reconocimiento de prerrogativas, franquicias y honras. De este modo, memoriales y probanzas permitieron a la nobleza indígena acreditar el honor social que les correspondía, reconstruir sus filiaciones y componer memorias familiares a las que recurrieron sus descendientes en diversos escenarios.

Hacia 1563, don Francisco Poma Urco Inga recibía la merced de que sus hijos, nietos y demás descendientes, pudiesen tener armas y caballos, como lo debían "los demás principales yngas deste Reyno", en razón de haber ayudado a los españoles "en la conquista e defenssa deste rreyno" ("Don Joan Francisco Vrco Supa natural del pueblo de Ansa, jurisdicción del corregimiento de Abancay, representado por el procurador general de los naturales", ABNB EC $1668 \mathrm{~N}^{\circ} 1$ ). En el siglo siguiente, sus descendientes fueron perdiendo la preeminencia, al punto que se les compelía al pago de tributos, la participación en las mitas y demás servicios personales, de los que tenía obligación el común de indios. En diversas ocasiones, los descendientes de Francisco Poma Urco Inga reclamaron para sí las honras y franquicias que les correspondían como tales descendientes. En 1658, los bisnietos de don Francisco Poma Urco Inga, descendientes por vía materna, volvieron a reclamar que se les reservase de tributos, mitas y ser- 
vicios personales. Los testigos presentados en dicha ocasión, pertenecientes a linajes de los incas principales, confirmaron que eran "yngas descendientes de Don Francisco Poma Urco Supa por ser hijos de Doña Francisca Poma Urco Supa nieta del susso dicho e como tales deven gossar de los privilegios que gossaron los dichos abuelos" ("Don Joan Francisco Vrco Supa natural del pueblo de Ansa, jurisdicción del corregimiento de Abancay, representado por el procurador general de los naturales", ABNB EC $1668 \mathrm{~N}^{\circ} 1$, foja $10 \mathrm{v}$ ). Martín Lerma, cuyo testimonio debió ser interpretado, y cuya edad frisaba los noventa años, declaró que "los sussodichos son hijos lexitimos de Don Pascual Cussi Guallpa y de doña Francisca Poma Vrco Suppa porque los bio criar y alimentar y son abidos e procreados durante el matrimonio que contraxeron". El mismo testigo declaraba que la mencionada dońa Francisca era hija legítima de don Martín Guaman Poma Urco, hijo de don Francisco, y, por tanto, su descendiente legítimo, agregando que aquel había obtenido y ganado provisión ejecutorial. Otros testigos, que habían sido caciques principales y cobradores de tasas, reconocieron que había sido el propio don Francisco quien los había colocado en tales cargos. Aunque parecían ya no contar con el suficiente poder e influencias que les había permitido probar su legitimidad en la década anterior, en 1658 nuevamente fueron afectados por la insistencia de alcaldes camachicos y mandones a que tributasen, fuesen a la mita y prestasen servicios personales.

Esta situación se repetía entre otros miembros del linaje de los incas principales. Los hermanos Mascapongo Yllatarco, naturales del pueblo de Copacabana, solicitaron en 1684 que se les permitiese gozar de los privilegios de nobles, por ser descendientes del Inca, por ser su abuela dońa Isabel Cusirimai descendiente de Tupac Inca Yupanqui y de Guaina Capac. La muerte de sus abuelos y de sus tíos los habían dejado huérfanos, por lo que "no alcanzaron las provisiones de resserua que tuvieron sus dichos agüelos de no pagar tributo como dichos desendientes de los dichos señores yngas" ("El fiscal, con don Onofre Mascapongo Ylatarco y hermanos, sobre sus privilegios de nobleza, como descendientes del Inca”, ABNB 1684, No 40, foja 2r). Por esto los Mascapongo Yllatarco reclamaban para sí la preemi- nencia que gozaron sus abuelos de no pagar tributo alguno. En 1675, ellos habían ofrecido información sobre su filiación, apoyados en el reconocimiento que había alcanzado su abuelo como bisnieto legítimo de Capac Yupanqui, y que sus padres no habían alegado, pero que sí se les reconocía a sus primos hermanos. Esta situación había provocado que estuviesen incluidos en el padrón de tributarios, con "agrauio tan grande para nuestros derechos", desconociéndose la voluntad real de desagraviar a "los hijos y deudos de los señores yngas" e impidiéndose que gozaran de las "preheminencias que gozan los hijosdalgo" ("El fiscal, con don Onofre Mascapongo Ylatarco y hermanos, sobre sus privilegios de nobleza, como descendientes del Inca", ABNB EC 1684 $\mathrm{N}^{\circ} 40$, fs. $3 \mathrm{r}-3 \mathrm{v}$ ). Con anterioridad habían dirigido un memorial al virrey Conde de Lemos, que fue recibido por el corregidor de la época, quien confirmó la filiación por autos, a partir de la información que entregaron el gobernador y los principales del pueblo de Copacabana.

Las familias de notables indígenas tenían la convicción de que los privilegios y honras que gozaban provenían de una nobleza heredada de sus ancestros. Basaban su honor en la transmisión ininterrumpida de esa condición, y en el reconocimiento público que los indios principales, y otros notables locales, proferían como testigos en pleitos o en alguna información de filiación. En 1684, los hermanos Ignacio y Francisco de Castilla presentaron un memorial a la Audiencia de La Plata para que se les reconociera y guardasen los privilegios correspondientes a caciques y nobles. En este memorial sostenían que por línea paterna y materna descendían de indios nobles, incluso de la propia descendencia de los Incas, y que en tal condición "sus abuelos paternos y maternos por nobles obtuvieron diferentes prouiciones de esta Real Audiencia, y del gouierno superior de estos reynos, para que se le guarden los preuilegios y exempciones de tales caciques, y que pudiesen traer espadas" ("Ignacio y Francisco de Castilla sobre que se les considere en los privilegios de sus padres, como descendientes del inca. Juli, Prov. de Chucuito", ABNB EC 1691 N$^{\circ} 20$, foja 1 r). Hacia 1685 volvieron a presentar la misma petición. En esta ocasión los testigos confirmaron que a los padres de los hermanos de Castilla se les te- 
nía por descendientes de caciques antiguos. De este modo, la información de filiación no solo permitió una acumulación de testimonios, sino que también constituyó un recurso fundamental para ennoblecer una genealogía familiar.

En virtud de estos reconocimientos, los hijos de Francisco Viracocha Inga, naturales del pueblo de Copacabana, solicitaron que se les amparase "en la poseçión de su nobleza y lisensia para traer espada y daga" ("Petición de don Juan Felipe, don Nicolas i don Bartolome hijos de Francisco Viracocha Ynga, naturales del pueblo de Copacabana para que se les acuerden los privilegios correspondientes a su nobleza, como usaba su padre", ABNB EC $1707 \mathrm{~N}^{\circ}$ 65 , foja $1 \mathrm{v}$ ), pero también que se les reconociese "por desendientes lexitimos del ynfiel Apu Inga Sucso Yup[an]que, rey y señor natural en la gentilidad, amparando[nos] en la noblesa de nuestros padres y antepasados para q[ue] [go]semos de los onores gracias y merczedes" (ABNB EC $1707 \mathrm{~N}^{\circ}$ 65, foja 2r ). En 1729, don Nicolás de Cáceres Tito Viracocha Inga, principal del pueblo de Copacabana, también presentó una petición para que sus hijos pudiesen traer espada y daga para adorno y defensa de sus personas, bajo el argumento de su condición de noble y estar en posesión "de los preuilexios y esempciones y prerrogatiuas que deuen gosar los hijosdalgo de Castilla" ("Expediente de don Nicolás de Caseres Tito Viracocha Ynga, sobre que los hijos puedan traer espadas y dagas para adorno de sus personas", ABNB EC $1729 \mathrm{~N}^{\circ} 30$, foja $1 \mathrm{r}$ ).

Pero esto no era privativo de quienes descendían del linaje de los "yngas principales", sino que también de una élite que se había ido articulando por su vinculación con las estructuras cacicales coloniales. Que los padres y abuelos, en el ejercicio del curacazgo hubiesen sido eximidos de tributos y obligaciones personales, llevaba a sus descendientes a representarse como indios nobles, por cuanto no se habían ejercitado en "seruicios bajos y viles", lo que era propio de "yndios de baja calidad", e incluso podían pretextar, manipulando las Leyes de Indias, de que a los indios "se les conmserben aquellos onores que gosaron de la gentilidad y no haserlos nunca de peor condición” ("Ambrosio, Joaquin y Felipe Mamani, indios principales del pueblo de Arapa, provincia de
Asangaro, pidiendo se les exima de la mita de Potosi por ser nobles, descendientes de caciques", ABNB Minas $1271753 \mathrm{~N}^{\circ}$ 1143, f. 1r). El nieto de un antiguo gobernador de parcialidad de Guancollos, perteneciente al pueblo de Juli, consideraba que dicha relación era prueba suficiente para "gosar de los privilegios y esenciones de yndios nobles" ("Reclamo del indio Francisco Chaves del pueblo de Gulo, provincia de Chucuito, para que se le exima del servicio de pongo, a que el casique le somete, por ser descendiente legitimo de gobernador", ABNB 1754 $\mathrm{N}^{\circ} 106$, foja $1 \mathrm{r}$ ). El protector general de indios avaló la petición del indio y sostuvo que por naturaleza se encontraba exento de realizar "los pesados servicios mecanicos”. Cuestión que también aprobó la Real Audiencia de La Plata en concordancia con lo que había obrado en el caso de don Joseph Araja, un indio principal del pueblo de Laja en la provincia de Omasuyo, quien consideraba que descender de caciques y capitanes mita era prueba suficiente para ser considerado indio noble, por lo que debía gozar "de los fueros y priuilegios de nobles, y que como tales no seamos molestados por los correxidores ni otros ministros, en seruicios bajos y mecanicos" (ABNB $1753 \mathrm{~N}^{\circ} 40$, foja $6 r$ ). Los miembros de esta nobleza indígena consideraban que desconocer, lo que ellos denominaban la primera nobleza del pueblo, significaba alterar y perturbar el orden propio "de los que son de nuestra esfera", rebajándolos a "indios ordinarios sin diferenciarnos de ellos", al obligarlos a "practicar los oficios de gente ordinaria" ("José, Juan y Gregorio Ticona, indios del pueblo de Uancane, provincia de Paucarcolla, pidiendo se les exima de la mita de Potosi por ser descendientes de indios nobles", ABNB Minas 127 1755, fs. 1r-v ).

La existencia de familias que pretendían pertenecer a la nobleza del pueblo era un obstáculo para aquellos que estaban ejerciendo el cacicazgo, con el aliciente que podían ser potenciales candidatos a ocupar esos cargos, por lo que, en algunas ocasiones, los caciques en ejercicio tendieron a desconocer el tratamiento de "yndio noble", quitándoles los instrumentos reales que celosamente resguardaban como prueba de su nobleza. El indio Francisco Chávez acusaba, hacia 1754, que el cacique interino del pueblo de Gulo, en la provincia de Chucuito, lo había obligado a servir en la mita de Potosí, tras lo cual lo forzó 
a servirle como pongo. Para el Fiscal de la Audiencia de Charcas, constituía un "desarreglado designio de mantenerlo en los pesados servicios mecanicos, de que por naturaleza se halla esento”, por lo que debía ser eximido y libertado "de la pencion de seruicios personales", lo que fue aprobado por la Audiencia (ABNB EC 1754, f. 1v ). En 1753, el indio Joseph Araja, principal del pueblo de Laza del ayllu Collana, se quejaba de que el cacique le había molestado "con los seruicios de pongo y pastor de mulas", habiendo sido capitán enterador de la mita de Potosí, en dos ocasiones, la última en la época del mencionado cacique, asumiendo los costos, "con toda su pobreza, y ha quedado adeudado porque para ellos se a balido de barias personas a quienes no ha dado satisfacción" ("Expediente de don Joseph Araja indio del pueblo de Lava, sobre que se le guarden todos los fueros y privilegios como a indio noble", ABNB EC $1753 \mathrm{~N}^{\circ}$ 40, f. 4r). A lo que se sumaba la arbitraria imposición de pagar tributo, con notable agravio de sus derechos y privilegios, y "por estar pobre" y "en las últimas necesidades porque sus cortas chacras se le an atrasado". Esto también lo habían experimentado sus dos hermanos, con el desconocimiento de que "los indios de esta calidad gosemos de los fueros y priuilegios de nobles, y como tales no seamos molestados por los correxidores casiques ni otros ministros en seruicios bajos y mecanicos de pongos pastores de mulas, ni otros de esta calidad", habida cuenta que se encontraba amparado en la posesión de noble por autos del corregidor del año de 1728 ("Expediente de don Joseph Araja indio del pueblo de Lava, sobre que se le guarden todos los fueros y privilegios como a indio noble", ABNB EC 1753 N40, f. 6r ). La Audiencia de La Plata libró una provisión real para que el corregidor de la provincia de Omasuyo le hiciese guardar "los fueros y privilegios que le están consedidos como a tal yndio noble sin permitir se le moleste ni ocupe en serbicios bajos" ("Expediente de don Joseph Araja indio del pueblo de Lava, sobre que se le guarden todos los fueros y privilegios como a indio noble", ABNB EC $1753 \mathrm{~N}^{\circ} 40$, f. $7 \mathrm{r}$ ).

Aunque empobrecidos, y carentes de los medios para vivir como lo hacía la alta nobleza indígena, estos indios nobles podían transmitir a su descendencia el prestigio de su nobleza y su pureza de sangre. De ahí la insistencia en que aquella fuese expresamente aclarada, pues se veía cuestionada, a los ojos del común, cuando eran obligados a realizar "seruicios mecanicos como pastear ovejas ser pongos y otras cosas que no deuen hacer los principales" ("Don Juan Caso hace constar que es indio noble desde sus abuelos según consta por los papeles que a la muerte de estos quedaron en poder de don Juan Nuñez", ABNB $1763 \mathrm{~N}^{\circ}$ 58, f. 1r ). En las informaciones sobre filiación, los testigos tendieron a reproducir la representación de que los demandantes, como era la situación de don Juan Caso y sus hermanos, vecinos del pueblo de Asillo, eran "hombre de sangre noble y se an ocupado en seruicios mui honrrosos", al igual que sus "padres que fueron mui nobles y de todos tenían portal por sus buenas costumbres e que lo mesmo son los hijos" (ABNB $1763 \mathrm{~N}^{\circ} 58, \mathrm{f}$. $2 \mathrm{v}$ ). En 1755, el padre de los hermanos Caso, don Francisco Caso, entonces cacique y gobernador de la parcialidad de Anansaya del pueblo de Ansillo, había solicitado, ante la pérdida de los instrumentos que lo calificaban como "eredero de la sangre noble de mis abuelos", que se aclarase su nobleza, pues los indios y principales del pueblo "quieren abandonar mi sangre noble con poco respecto" (ABNB 1763 $\mathrm{N}^{\circ} 58$, f. 5r ). Para el cacique, esta aclaración de nobleza era necesaria para que le viesen y conociesen por tal, particularmente "dándoles a conocer al vulgo para que guarden mis fueros y me conozcan por tal [noble]".

\section{La nobleza indígena en el siglo XVIII}

Desde la segunda mitad del siglo XVIII, algunos miembros de la burocracia imperial mostraron un creciente recelo frente a la nobleza indígena y sus lugares de memoria. Los nobles indígenas fueron visualizados, parafraseando al virrey José Antonio Manso de Velasco, como una fuente de alteración nociva para el cuerpo político. El mismo virrey del Perú señalaba que en las solemnidades públicas, en que se proclamaba el nacimiento de príncipes, los indios no debían distinguirse por gremio separado, sino que en los que correspondiese a sus oficios. Más aún sostenía que tampoco debía permitírseles "la representación de la serie de sus antiguos Reyes con sus propios trajes y comitiva: memoria que en medio del regocijo los entristece, y pompa que les 
excita el deseo de dominar y el dolor de ver el cetro en otras manos que las de su nación" (Memorias, 1859, IV, p. 102).

La rebelión general de 1781 no hizo más que acrecentar los temores hacia las élites indígenas, a pesar de que la mayor parte de estas se mantuvieron fieles al gobierno colonial (O'Phelan, 1995). En 1782 , se tomaron diversas medidas para neutralizar la influencia de los caciques y la nobleza indígena, eliminando el carácter hereditario de los cacicazgos, en un esfuerzo por "hacer olvidar, a los indios, a sus antiguos reyes" (Hidalgo, 1986, p. 340). Incluso sectores de la nobleza indígena del Cusco trataron de tomar distancia del simbolismo político inca y "redoblaron sus esfuerzos por construir su propia identidad colectiva, autorrepresentándose como pilares de la corona y de la iglesia" (Cahill, 2003, p. 81). A pesar de estos esfuerzos, las críticas continuaron en los años siguientes. En 1786, el virrey Teodoro de Croix sostenía que la instrucción de caciques e indios nobles había tenido efectos desastrosos. A su juicio, la educación dispensada en el Colegio de Naturales había criado caudillos formidables, provistos de luces intelectuales, que podrían inquietar y hacer temblar el dominio español. De ahí que el virrey considerara que "sería la máxima más disparatada del mundo, en mi dictamen, instruirles y educarles en las ciencias, avriéndoles los ojos para que formen proyectos concertados, alianzas poderosas, y preparen y conduzcan con arte y disimula alguna sublevación" "“Carta reservada n 40 de Teodoro de Croix, Virrey del Perú, a Josè de Gàlvez, Secretario de Indias", AGI Lima 669, N. 54, f. 2 r). Además, entre las razones que el virrey Teodoro de Croix entregó para la creación de un obispado que abarcara las provincias de Collao, Azángaro, Lampa y Caraballa, estaba el hecho de que estas provincias eran abundantes de indios y escasas de españoles, situación que había incidido en la fuerza que la rebelión había tenido en estas provincias. Por lo que esperaba que el establecimiento de un obispado en una de estas provincias permitiría que fuesen pobladas por gente española para que "se hiciese respetar de los Indios nobles, que son los que conmueven é inquietan á la plebe" (Memorias, 1859, V, p. 107).
No obstante las aprensiones del virrey del Perú, varios caciques y nobles indígenas de Charcas fueron premiados por su lealtad al monarca en el transcurso de la sublevación. Con esta medida se extendía lo obrado por el presidente de la Audiencia de La Plata quien, en 1781, había premiado con una medalla del busto del monarca a los caciques de Porco y Yamparaez. Una posición que también expresaron autoridades menores, como los indios principales de la hacienda de Guaicoma (doctrina de Poroma, provincia de Yamparaez), a quienes se declaró "por fieles vasallos del Rey, y se les dan en nombre de S. M. las correspondientes gracias", prometiéndoseles "la dispensación de otros privilegios, franquezas y honores con que sabe premiar la poderosa mano del Rey" ("Presentación de los yndios principales de la hazienda de Guaycoma la baja para que se les declare por fieles y leales basallos", ABNB SGI 45, fs. 1v-2r). Probablemente, estas medallas debieron inspirarse en las Medallas al Mérito que Carlos III confirió, en 1764, a los oficiales de milicia que defendieron La Habana (Villena, 2004). El visitador general Joseph de Gálvez señalaba al virrey que arbitrase las medidas para que "facilite igual premio a los indios caciques, y nobles que lo merezcan, constando indubitablemente su fidelidad, y servicios en las pasadas sublevaciones, y dejando al arbitrio de usted las que hayan de ser de ôro, ô de plata, según para, los sugetos a quienes hayan de distribuirse" ("Nota en que trascribe el excmo sor virrey la aprovasion de S.M. de la medalla conferida a los casiques leales", ABNB SGI 309). Antes de esta disposición, la Audiencia de La Plata había premiado a otros caciques, como al gobernador de Todos los Santos de Yotala, quienes debieron enviar relación de sus méritos ("Informe de don Clemente Azurduy, cacique principal y gobernador de todos los Santos de Yotala, al gobernador intendente", ABNB SGI 309, f. 3 r). Pero quienes habían recibido la medalla, como el cacique gobernador don Francisco de Luna de Zárate, del pueblo de Porco, podían presentarse sin más como "caballero, noble de la medalla de oro" o, como el propio don Clemente Azurduy, como "caballero del distinguido orden del merito" (ABNB SGI 264, f. $1 \mathrm{r}$ ). De este modo, el grupo de caciques leales resignificaba la medalla como un atributo de su nobleza, de su pertenencia a una orden y se homologaba al estatus de caballero. 
Pero también otros miembros de las élites indígenas se vieron obligados a esclarecer las sospechas que rondaban respecto de su participación en la sublevación. Para esto fueron respaldados por algunas autoridades locales, como fue el caso de don Lázaro Poma, alcalde ordinario de la parcialidad de Quillaca del pueblo de Challapata, quien pretendía ocupar el cargo de alcalde provincial de aguas bajo la convicción de "ser fiel y leal basallo de S. M. que sabra con el deuido honor celo, y amor al real seruisio desempeñar deuidamente y con este nuebo ministerio, sugetar los animos de los naturales que quieren seguir los yerros que cometieron" ("Expediente de Casimiro Puma en que consta no haberse mesclado en la sublevacion”, ABNB SGI 140, f. 3r).

\section{Adperpetuam rei memoriam: prácti- ca jurídica y comunidad de memoria}

El presbítero Nicolás Tadeo de Miranda, vecino y hacendado del pueblo de San Pedro de Muqu Muqu, tenía mayores motivos para esclarecer su participación en la rebelión promovida por los tupacamaristas, pues no solo arriesgaba perder su posición social, sino que arrastrar a la deshonra a toda su casa. $\mathrm{Y}$ esto no únicamente porque había una sospecha generalizada hacia la clerecía local, por cuanto algunos de sus miembros se habían involucrado con los rebeldes, particularmente en las áreas dominadas por estos, "debido al oportunismo o a la desesperación" (Walker, 2015, p. 101), como fue el caso del también presbítero don José Vásquez de Velasco del curato de Chocaya en la provincia de Chichas ("Testimonio del expediente seguido contra el presvitero d. Jose Basquez de Belasco por complice en la sublevacion de la provincia de Chichas", ABNB SGI 201). Además, la familia de don Nicolás Tadeo de Miranda alegaba descender de Viracocha Inga y de Alonso Tito Atauchi, y por esa vía de los señores naturales incas, y en tal condición los miembros de su casa habían recibido honras y privilegios como indios nobles. Un aspecto que el presbítero omitió, como se verá a continuación, en una presentación que hizo en 1786.

Hacia 1786, el licenciado don Nicolás Tadeo de Miranda ejercía de teniente de cura en la provincia de Larecaje. En la misma provincia, sus hermanos des- empeńaron los cargos de sargento mayor, capitán y alférez de infantería respectivamente. Todos fueron hijos del maestre de campo don Tomás de Miranda y de dońa Bernarda de Escobar. Por vía materna, los hermanos de Miranda se vinculaban a la familia del capitán don Francisco Rodríguez de Escobar, un antiguo dueño de minas en el asiento de San Antonio de Esquilache en Lípez, y que había realizado denodados esfuerzos, entre las décadas de 1670 y 1680 , por obtener la confirmación real como descendiente de los Incas para sí y sus hermanos. Además, los hermanos de Miranda se beneficiaron del capital social (Bourdieu, 1980) que les reportaba las redes productivas, eclesiásticas y militares a las que estuvieron vinculados sus ascendientes y que ellos habían reproducido y ampliado.

Indudablemente que el prestigio acumulado no podía quedar expuesto a la lenta erosión del rumor que vinculaba a don Nicolás Tadeo de Miranda con la sublevación de 1781 . Si él permitía que esos rumores circularan sin ponerles atajo, podía verse expuesto a la deshonra de no ser un fiel vasallo de una monarquía que había otorgado a su casa honras y franquicias. Así como el honor no era una virtud individual, sino que era algo que un individuo portaba por su pertenencia familiar, y a los que contribuía individualmente en su conducta social, tampoco lo era la pérdida del honor. En estricto rigor, un individuo de la posición social del licenciado Nicolás de Miranda tenía escasa capacidad para maniobrar fuera de las redes familiares. Por lo que presentó un interrogatorio para que se examinase a testigos que declararan sobre sus buenas costumbres como eclesiástico y su comportamiento durante la rebelión, en la que se habría dedicado a su labor pastoral y a predicar la sujeción al monarca. Tal como lo habían hecho otros descendientes de Tito Atauchi, como Andrés Rojas Tito Atauchi, abogado de la Audiencia de La Plata hacia 1797, a quien se le reconocía su descendencia de indios nobles, y la lealtad que habían observado, él y su padre, durante la rebelión; el primero desempeńándose como intérprete en $\mathrm{La}$ Plata y el segundo como alcalde mayor en Potosí (“Solicitudes e instancias de parte 1786-1821", AGI Charcas 734). Para el presbítero no solo se trataba de aclarar su honor, sino que de impedir que la deshonra alcanzase a su familia con la subsecuente 
pérdida de privilegios y prerrogativas. Como se ha señalado, en sociedades obsesionadas por "la reputación personal y familiar, la irrupción de una ofensa pública de naturaleza grave imprime un desorden intolerable, una alteración en la imagen que no puede ser soslayada" (Fernández, 1999, p. 14). De ahí entonces la necesidad de recurrir a la justicia para reparar los efectos de la injuria y aclarar el honor. Una vez reunido los testimonios, don Nicolás Tadeo de Miranda solicitó al Promotor Fiscal de la ciudad de La Paz que se sirviese "en inteligencia declararme por libre de toda calumnia, que no tube deprabada intencion, ni mal fin en la sublevacion pasada, que obre conforme a mi fidelidad y lealtad, en obsequio del estado, de la propia magestad" ("Conducta del pbro. Nicolás T. Miranda en la rebelión. 1784-XII15", Archivo Eclesiástico Arzobispado de La Paz, vol. 91, foja $29 \mathrm{v}$ ). Este recurso judicial permitió a Nicolás Tadeo de Miranda aclarar su honor y dignidad o, para decirlo en sus palabras, "correr el velo del rumor con que se ha pensado calumniarme".

En agosto de 1791, el fiscal del rey no encontró reparo alguno para librar un despacho favorable al licenciado Nicolás Tadeo de Miranda, reconociéndole las honras, privilegios y excepciones que le correspondían como descendiente por línea materna de los incas señores naturales. En su presentación, no hizo ninguna mención a los rumores que unos años atrás debió aclarar respecto de su supuesta participación en la rebelión de 1781, pero incorporaba un aspecto que no había incluido en 1786, precisamente la filiación con la nobleza inca. La vinculación con Alonso Titu Atauchi y con Viracocha Inca se apoyaba en un entramado genealógico laboriosamente tejido a partir de sucesivas informaciones de filiación, que se remontaban a la última década del siglo XVI. Los ascendientes del presbítero Nicolás Tadeo de Miranda habían ido construyendo esta trama a través del entroncamiento con familias de la nobleza indígena, lo que permitía identificarse parentalmente con algún ancestro inca, como lo ha demostrado Choque (2014) para el caso de los caciques de Pakasa. Por su parte, los ascendientes de la familia Miranda habían incorporado una nutrida información documental para demostrar la filiación parental con el linaje de los Viracocha Inca cuyos vínculos con el santuario de Copacabana han sido analizados por Del Río (2009).
En años anteriores, el propio Nicolás Tadeo de Miranda había recurrido a la justicia para que reconociesen la filiación familiar con el linaje de los Incas. En 1776, el presbítero había logrado que él y sus hermanos fuesen confirmados en la "posecion de nobles descendientes de los incas seńores naturales que fueron de estas prouincias del Perú”, tal como había sido determinado por las reales cédulas de 1767 y de 1725 ("Obrado a instancias de don Jose Palavicino como apoderado del licenciado don Nicolás Tadeo de Miranda clérigo presbítero domiciliario del obispado de La Paz, sobre los privilegios y excenciones que a este corresponde como descendiente de don Alonzo Tito Atauche Inca, etc", AGNA Justicia, leg. 27, Exp. 784, f. 44 r). Hacia 1780, el presbítero presentó estos papeles a la Audiencia de La Plata para que surtiese el efecto esperado, es decir, que las autoridades civiles y eclesiásticas de La Paz y de la provincia de Larecaja guardasen, a él y a sus hermanos, las honras y privilegios debidos a su condición de indios nobles. No debe verse en esto una mera estrategia individual, él no podía sustraerse del marco de la memoria familiar y del patrimonio de su linaje, más aún considerando que su propio abuelo materno, el capitán Francisco Rodríguez de Escobar, había producido una información ad perpetuam rei memoriam con el propósito de probar que era hijo legítimo de "Diego Rodríguez de Escobar y de doña Mencia de Cazeres y Abendaño y nieto de doña Gracia de Cazeres Pillco Sisa Coyo y visnieto de don Pablo de Cazeres, y de don Alonzo Tito Atauche y de sus [...] desendientes" ("Petición de filiación del capitán Francisco Rodríguez de Escobar. Cuzco, 22 de septiembre de 1682", AGNA Justicia, leg. 27, Exp. 784, foja 4 r). Los testigos presentados por don Francisco Rodríguez declararon que comúnmente habían escuchado que doña Gracia de Cáceres Pillco Sisa Coyo era "de la sangre real del Inga Ttito Atauchi”, lo que también podía ser avalado por el parentesco que guardaba con Lope Josef Mayta Capax Tito Atauchi, primo suyo y gobernador en ese entonces del pueblo de Copacabana. El hermano de este gobernador, don Pascual Mayta Capax Tito Atauchi, cacique principal del mismo pueblo, declaró que los hermanos Rodríguez de Escobar eran de la descendencia "de don Alonzo Ttito Atauchi y nietos lexítimos de Viracocha Inga señor natural que fue de estos reynos del Peru", como lo probaban 
suficientemente las cédulas, títulos e instrumentos conferidos a esta línea o sangre, además que tal condición estaba socialmente reconocida en Copacabana y en el Cusco "sin hauer cosa en contrario como este testigo lo es, de la dicha desendencia” (AGNA Justicia, leg. 27, Exp. 784, foja 7r ). El corregidor Nuño Espínola Villavicencio, corregidor de la ciudad del Cuzco, aprobó la información contenida y declaró a Francisco Rodríguez como descendientes de los señores naturales, otorgándole el goce correspondiente de los privilegios de nobleza.

La probanza de 1682 se había apoyado en un par de testigos y en documentos referidos al reconocimiento de nobleza que se había hecho a la familia de los primos de Francisco Rodríguez de Escobar. El primero correspondió a una petición de don Carlos Inga de Valladares, presentada en 1671, en la que solicitaba se le diera traslado de dos cédulas otorgadas por Carlos V a don Alonso Tito Atauchi, "hijo de Guascar Inga mi bisabuelo de alcalde mayor de todo este reyno del Peru, y priuilegio de lexitimacion y blazon de aramas" ("Petición de don Carlos Inga de Valladares. Cuzco, abril de 1671", AGNA Justicia, leg. 27, Exp. 784, foja 8r). Un segundo documento correspondió a una petición realizada en 1651 por don Josef Arenas Florencia Inga, quien se declaraba como "visnieto lexitimo de don Alonzo Tito Atauchi Inga y nieto lexitimo de Guayna Capax inga" ("Petición de don Joseph Florencia Inga. Potosí, 28 de marzo de 1651", AGNA Justicia, leg. 27, Exp. 784 , foja $8 v$ ), alterando la sucesión genealógica de sus ascendientes. A partir de esta petición se había incorporado un tercer documento correspondiente a otra, presentada por los padres de Josef Arenas Florencia Inga, en la que se declaraba que su madre, dońa Jerónima de Florencia Santa Ángel Coya, era nieta de Alonso Tito Atauchi, por lo que solicitaban, para guarda de su derecho, el de sus hijos y sucesores, que se les diese traslado de las mencionadas cédulas ("Petición de don Alonso de Arenas y de doña Gerónima de Florencia Santa Angel Coya. Cuzco, octubre de 1623", AGNA Justicia, leg. 27, Exp. 784, foja 9v). Las cédulas fueron incorporadas al expediente.

El vínculo con la prestigiada figura de Alonso Tito Atauchi suscitó una cierta suspicacia entre algunos miembros de audiencia. El fiscal sostuvo que no se encontraba suficientemente probado que la abuela de Francisco Rodríguez fuese descendiente del Inca, y recordó que "en estas materias se deuen presentar fees de baptismos para que se pruebe la filiacion por la mucha facilidad de hazerse desendiente del Inga" ("Presentación del Fiscal. Lima, marzo 27 de 1684", AGNA Justicia, leg. 27, Exp. 784, foja 16v). Por su parte, Francisco Rodríguez consideraba que su petición no perjudicaba a ningún tercero, agregando que había muchos interesados en obtener la merced de ser reconocidos como incas y que tampoco había sido contradicha su propia pretensión; respecto de la fe de bautismo sostuvo que el descuido de los curas y los incendios impidieron la conservación de este documento. El fiscal pareció restar valor a los testimonios de oídas, y al intento de probar filiaciones con los Incas de manera indirecta, pero Francisco Rodríguez recurrió al derecho consuetudinario para apoyar su pretensión, pues "el fundamento y verificación de un hecho tan antiguo la singularidad de ello [...] bastaba en llanas dispociciones de derecho la notoriedad la publica voz y fama" (AGNA Justicia, leg. 27, Exp. 784, foja 17v). No obstante, la contradicción del fiscal llevó a Francisco Rodríguez a incorporar un documento escrito que pudiera servir de mejor respaldo a sus pretensiones. En 1622, su bisabuelo materno, junto a un crecido número de familiares, solicitaron que se les reconociera como nobles y como parte "de una misma casa del señor Viracocha Inga por ser como somos hijos y nietos y sobrinos del dicho señor, y en esta posecion emos estado y estamos asi en la dicha ciudad del Cusco como en este pueblo y nos tratamos y comunicamos" (AGNA Justicia, leg. 27, Exp. 784, foja $18 \mathrm{v})$. Entre otros más, este procedimiento permitió a don Pablo de Cáceres Viracocha Inca ser reconocido como descendiente de Viracocha Inga y quedar reservado de tributos. Dado que la filiación con Alonso Tito Atauchi no había sido suficientemente probada, e incluso cuestionada por el fiscal de la $\mathrm{Au}$ diencia, este documento de 1622 ofrecía un mejor fundamento a la pretensión de nobleza de Francisco Rodríguez de Escobar.

Con anterioridad a su presentación de 1684, el capitán Francisco Rodríguez de Escobar había aclarado la filiación de su madre con el claro propósito 
de que sus descendientes no se viesen contrariados en futuros procedimientos. La madre de Francisco Rodríguez, y bisabuela de don Nicolás Tadeo de Miranda, era hija natural de doña Gracia Pillco Sisa y de Tomás Delgadillo. Los testigos sostuvieron que Mencia de Cáceres y Avendańo fue criada como hija por doña Gracia de Cáceres Pillco Sisa y reconocida como nieta por don Pablo de Cáceres. Los testimonios fueron suficientes para que el corregidor de la provincia de Umasuyo aprobase la filiación de don Francisco Rodríguez como "nieto de dońa Gracia de Cazeres y visnieto de Pablo de Cazeres Viracocha Inga" (AGNA Justicia, leg. 27, Exp. 784, foja 22r). El vínculo con este último fue relevante para fundamentar su descendencia de los Incas.

El archivo familiar de Francisco Rodríguez contaba con más documentación para ser presentada ante la Audiencia. En 1610, don Pablo de Cáceres Challco Yupanqui había solicitado a la Corona se le hiciera merced, para sí y sus descendientes, de una renta de cuatro mil pesos ensayados "con la declaracion que ayan de gozar de las exepciones, priuilegios, franquezas, y liuertades de que gozan los caualleros hijosdalgos" (AGNA Justicia, leg. 27, Exp. 784, foja 26v). Esta retribución la solicitaba por cuanto no podía sustentarse conforme a la calidad de su persona y porque sus padres habían fallecido pobres por los gastos que sus antepasados habían comprometido en el real servicio, lo que se encontraba probado suficientemente en una información de 1597. En este documento don Pablo de Cáceres Challco Yupanqui y don Alonso Virachocha Inca, en nombre de sus sobrinos, hijos y descendientes, se presentaban como nietos de Challco Yupanqui Inga y bisnietos de Viracocha Inca. En la información señalaban que su abuelo Challco Yupanqui había sido "gouernador de los indios collasuyos que es desde Villcanota hasta Chile nombrado por el Inga Guayna Capax su hermano que como tal hermano le dio el tal gouierno y en este tiempo vinieron y pasaron los españoles a estos reynos y un capitan llamado don Diego de Almagro con mucha gente, y con un inga llamado don Christoual Challco Yupanqui" (AGNA Justicia, leg. 27, Exp. 784, foja 27v). Esto habría llevado a Challco Yupanqui a servirles, gastando su hacienda y permitiendo el paso entre las charcas y los indios chichas, lo que habría provocado el enojo de Man- co Inca, quien lo envió a asesinar. En el relato de los testigos, que en gran parte descansaba en la voz pública y común opinión, se estableció un conjunto de relaciones: Challco Yupanqui como hermano de Guaina Capac e hijo de Viracocha Inca. Esto se imponía como algo notorio y permitía agregar otra relación: Challco Yupanqui como padre de Gonzalo Churatupa y Baltazar Challco Yupanqui Inca. A partir de esta se ingresaba a un terreno que podía ser probado documentalmente, pues Gonzalo Churatupa y Baltazar Challco tuvieron hijos habidos en legítimo matrimonio. Del matrimonio de don Baltazar Challco Yupanqui Inca y de dońa Ana de Avendaño nacieron Alonso Viracocha Inga y don Pablo de Cáceres Challco Yupanqui.

La información de 1597 configuró un relato fundador para los descendientes de don Pablo de Cáceres Challco Yupanqui y de don Alonso Viracocha Inca. Esto les permitió entroncarse con la casa de Viracocha Inca sin que tuviesen que enfrentar cuestionamientos posteriores. A lo que pudo haber ayudado también el vínculo que los hermanos Alonso Viracocha y Pablo de Cáceres tuvieron con el surgimiento del culto a la virgen en Copacabana (Ramos, 1976, pp. 115-121 [1621]).

Pero parte del relato fundante se apoyó en una fabulación que se transformó en un componente imprescindible de la memoria familiar durante el siglo XVII. No obstante, la memoria familiar conservó la filiación con Alonso Tito Atauchi, aprovechando lo sancionado por la probanza $A d$ perpetuam rei memoriam de 1682. En esta, los testigos, junto con recoger la voz pública, entroncaron a la madre de Francisco Rodríguez con Alonso Tito Atauchi apoyados en que a algunos de sus familiares se les había reconocido dicha filiación. Pero estos no necesariamente correspondieron a parientes consanguíneos, sino que a parientes políticos. En 1774, los testigos que presentó el presbítero Nicolás Tadeo de Miranda aún seguían dando crédito al relato familiar. El capitán Rafael de Cárdenas, quien fue vecino del pueblo de San Pedro de Muqu Muqu, declaró que sabía "por noticias de los antiguos que [Nicolás Tadeo de Miranda y sus hermanos] son acrehedores lexitimos a la nobleza y mersed que su magestad se siruio hazer a don Alonzo Ttito Atauchi visabuelo" 
(AGNA Justicia, leg. 27, exp. 784, foja 51r). Por su parte, otro testigo señaló que "oyo dezir bulgarmente que la tal dońa Bernarda Rodríguez de Escobar era desendiente de don Alonzo Tito Atauchi como porque varias vezes le hauia dicho a este declarante la tal dońa Bernarda que era de esa desendencia" (AGNA Justicia, leg. 27, Exp. 784, foja 51v).

\section{Observaciones finales}

En este trabajo se ha avanzado en la comprensión de los procesos que permitieron la apropiación de pautas identitarias nobiliarias castellanas por parte de los notables indígenas del área de Charcas. Aunque la historiografía suele otorgar un momento clave en estos procesos a la denominada cédula de honores de 1697, sin embargo, el análisis de la documentación permite evidenciar que las estrategias de homologación a la condición de hidalgos y nobles se encuentra presente desde la segunda mitad del siglo XVI. En el caso de Charcas, el Memorial de los Mallku de 1582 es bastante indicativo de esos procesos tempranos de apropiación por parte de los notables indígenas. Pero, a diferencia de lo que ocurrirá en el siglo XVII y XVIII, estos notables indígenas tendieron a legitimarse mayormente por sus vínculos con los seńores naturales anteriores a los incas. Pero no tuvieron dificultad en producir con posterioridad una filiación inca, como fue el caso de la familia Guarache, que de haber resaltado, en el siglo XVI, su vinculación con Apo Guarache, remarcaban en su escudo de armas, al finalizar el siglo XVIII, su relación con los "Novilisimos Ingas Tituatauchis de la prosapia de Guayna Capac” (Gisbert, 2004, p. 161).

Desde fines del siglo XVI, los notables indígenas incorporaron las pautas identitarias propias de la ideología nobiliaria castellana. De esta manera se puede apreciar la temprana resignificación, entre los indios nobles, de un ethos estamentario fundamentado en la pureza de sangre como criterio de diferenciación respecto de los indios bajos. Los diversos memoriales y probanzas han permitido explorar los discursos y representaciones predominantes entre la nobleza indígena: la convicción de pertenecer a una casta o linaje cuya sangre era noble y cuyas virtudes y cualidades los diferenciaban del común de indios; la aspiración a heredar las franquezas, honras y liberta- des de los ascendientes; la traducción del vocabulario nobiliario a las lenguas generales; la vinculación entre servicios honrosos y la condición de indio noble, entre otros aspectos que se han descrito en este trabajo.

Aunque estas pautas identitarias fueron compartidas por los notables indígenas, sin embargo, esto no debe conducir a pensar en ellos como un grupo homogéneo. La economía monetaria había impactado negativamente entre algunas de las familias indígenas, asociadas tradicionalmente a la calidad de nobles, dejándolas empobrecidas. Incluso muchas habían perdido el capital social y el prestigio reconocido a sus antepasados, quedando a merced de las arbitrariedades de autoridades indígenas de sus pueblos de origen. Pero aun en estos casos mantuvieron la convicción de que no podían ser homologados a indios bajos, por lo que recurrieron a la justicia para el resguardo de su honra y el reconocimiento de su estatus de hidalguía. Junto con estos fenómenos de descenso social, se observa una tendencia al ennoblecimiento entre algunas familias indígenas, alentada por la ocupación de un cargo en la estructura indígena. En este sentido, se manipuló la relación entre servicios honrosos (cacique, cacique cobrador o de capitán enterador de la mita) y la calidad de nobleza de quien ostenta el cargo. De esta manera algunas familias lograron cartas ejecutorias de nobleza apoyadas en el testimonio de que sus padres o abuelos habían ostentado el cargo de cacique, sin que necesariamente haya correspondido a una sucesión.

Con independencia de las circunstancias de su origen, las cartas ejecutorias y las probanzas permitieron legitimar estrategias familiares de ennoblecimiento y diferenciación social. La práctica jurídica otorgó un campo de posibilidad para la legitimación de los relatos de las memorias familiares, permitiendo la selección, reinvención y/o conservación de líneas directrices e imágenes identitarias. Muchas de las cartas ejecutorias se libraron en el espacio local, aprovechando las estrechas relaciones familiares $y$ sociales y los vínculos con los corregidores.

En la segunda mitad del siglo XVIII, particularmente tras la rebelión de 1781, pareció no haber un 
escenario propicio para quienes intentaban el reconocimiento correspondiente a los descendientes de la nobleza indígena. Solo unos ańos antes, en 1776, Nicolás Tadeo de Miranda había logrado que se le reconocieran a él y a sus hermanos las honras debidas a los descendientes de los señores naturales. Sin embargo, tuvo que enfrentar los rumores y la injuria que lo vinculaban con los rebeldes tupacamaristas, pero logró sortear la situación recurriendo a la justicia. Los rumores pudieron haberse suscitado por el hecho que algunos clérigos habían apoyado a los rebeldes. Pero es más plausible que estos rumores se hayan suscitado por el vínculo del presbítero con la nobleza inca. Esta última no aparece mencionada en ninguna parte de la solicitud que realizó para el examen de testigos que probaran su lealtad a la monarquía durante la rebelión.

El caso de la familia de Miranda permite insistir sobre algunos aspectos. En primer lugar, la noción de seńorío natural de los incas se utilizaba sin suscitar mayores inconvenientes entre los funcionarios de la Audiencia de La Plata y del virreinato del Río de La Plata. Tras cerca de dos siglos, la memoria familiar privilegió los vínculos con los incas de sangre como Viracocha Inca y Alonso Tito Atauchi que se articularon como núcleo fundante para diversas familias principales. Esto fue el resultado de la capacidad de maniobra que tuvieron los ascendientes de la familia de Miranda, quienes no solo se apropiaron de la cultura jurídica colonial, sino que también la incluyeron como parte de una estrategia familiar que fue efectiva para la obtención de honras y privilegios. Asimismo, esta estrategia permitió legitimar un relato que pudo presentarse en correspondencia con la voz pública y fama.

\section{Agradecimientos}

Este trabajo forma parte del proyecto FONDECYT 1130667 "Historia de los pueblos andinos de Arica, Tarapacá y Atacama: dinámicas imperiales, agencias indígenas y redes andinas de sociabilidad colonial, siglos XVI-XIX". Versiones preliminares y apartados de este trabajo fueron presentadas en el Seminario de Etnohistoria "Indígenas y Colonizadores en Pica y Matilla (UTA, Pica, 2016), $55^{\circ}$ Congreso Internacional de Americanistas (San Salvador, 2015), Congreso
Internacional de Etnohistoria (Arica, 2014) y en el VI Taller de Historia Andina (Viña del Mar, 2014). Agradezco los comentarios, correcciones y recomendaciones bibliográficas de Jorge Hidalgo Lehuedé, Soledad González Díaz, Itamar Olivares Iribarren y de los evaluadores anónimos del manuscrito.

\section{Referencias citadas}

Alfonso X (1576). Las siete partidas. Salamanca: Domingo de Portanariis y Ursino Impresor.

Álvarez, B. (1998 [1588]). De las costumbres y conversión de los indios del Perú. Rubio, M. del C., Villarías, J., y Del Pino, F. (Eds.). Madrid: Ediciones Polifemo.

Amphoux, P., y Ducret, A. (1985). La mémoire des lieux. Cahiers internationaux de sociologie, 79, 197-202.

Arze, S., y Medinacelli, X. (1991). Imágenes y presagios. El escudo de los Ayaviri, Mallkus de Charcas. La Paz: HISBOL.

Baranda, N. (1995). Escritos para la educación de nobles en los siglos XVI y XVII. En Bulletin Hispanique, 97(1), 157-171.

Bertonio, L. (2008 [1612]). Vocabvlario de la lengua aymara. Edición fascimilar en dos partes. La Paz: Instituto de Estudios Bolivianos.

Bourdieu, P. (1980). Le capital social. En Actes de la recherche en sciences sociales, 31(1), 2-3.

Bridikhina, E. (2007). Theatrum mundi. Entramados del poder en Charcas colonial. La Paz: Plural Editores - IFEA.

Burke, P. (2000). Formas de historia cultural. Madrid: Alianza Editorial.

Burns, K. (2005). Dentro de la ciudad letrada: la producción de la escritura pública en el Perú colonial. Histórica, XXIX(1), 43-68.

Cahill, D. (2003a). Nobleza, identidad y rebelión: los incas nobles del Cuzco frente a Túpac Amaru (1778-1782). Histórica, XXVII(1), 9-49.

Cahill, D. (2003b). Una nobleza asediada: los nobles incas del Cuzco en el ocaso colonial. En Cahill, D., y Tovías, B. (Eds.). Elites indígenas en los Andes. Nobles, caciques y cabildantes bajo el yugo colonial. Quito: Ediciones Abya-Yala. 
Carrasco, A. (2000). Sangre, honor y privilegio: la nobleza española bajo los Austrias. Barcelona: Editorial Ariel.

Carrillo, G. (2006). "La única voz por donde los yndios pueden hablar": estrategias de la elite indígena de Lima en torno al nombramiento de procuradores y defensores de indios (1720-1770). Histórica, XXX (1), 9-63.

Castro, N. e Hidalgo, J. (2008). Usos del pasado y memoria familiar. Diálogo Andino, 32, 21-43.

Castro, N., e Hidalgo, J. (2016). Las políticas de la lengua y su recepción en la audiencia de Charcas, siglos XVIXVIII. Diálogo Andino, 50, 181-206.

Choque, R. (2014). El parentesco entre los caciques de Pakasa. En Arnold, D. (Ed.). Gente de carne y hueso. Las tramas de parentesco en los Andes (pp. 325-340). La Paz: Fundación Xavier Albó, Instituto de Lengua y Cultura Aymara.

Cordero, M. (2017). Reproducción y traducción de la cultura judicial hispana en el imaginario indígena. Gobernación de Chile, siglos XVII y XVIII. Estudios de Historia Novohispana, 57, 8-26.

Covarrubias, S. (1611). Thesoro de la lengua castellana, o española. Madrid: Luis Sánchez Impresor.

Cruz, P. (2016). Imágenes en pugna. Reflexiones en torno a las producciones visuales indígenas en el ámbito de la minería colonial. Boletín del Museo de Arte Precolombino, 21(1), 95-113.

Eeckhout, P., y Danis, N. (2004). Los tocapus reales en Guamán Poma: ¿una heráldica incaica? Boletín de Arqueología PUCP, 8, 305-323.

Elias, N. (2012). La sociedad cortesana. México D.F.: Fondo de Cultura Económica.

Escobari, L. (2001). Caciques, Yanaconas y extravagantes. La sociedad colonial en Charcas s. XVI-XVIII. La Paz: Plural Editores.

Escobari, L. (2011). De caciques nobles a ciudadanos paceños. Historia, tradición y genealogía de los Cusicanqui, s. XVI a XXI. La Paz: Garza Azul Impresores y Editores.

Espinoza, C. (2015). El inca barroco: politica y estética en la Real Audiencia de Quito, 1630-1680. Quito: Flacso Ecuador.
Fernández, M. (1999). Familias en conflicto: entre el honor y la deshonra. Boletín del Instituto de Historia Argentina y Americana "Dr. Emilio Ravignani", tercera serie, 20, $7-43$.

Garret, D. (2009). Sombras del imperio: la nobleza indigena del Cuzco, 1750-1825. Lima: Instituto de Estudios Peruanos.

Gisbert, T. (2004). Iconografia y mitos indigenas en el arte. La Paz: Editorial Gisbert y Cía.

Glave, L. (2011). Memoria y memoriales: La formación de una liga indígena en Lima (1722-1723). Diálogo Andino, $37,5-23$.

González, S. (2015). Del Génesis a los Andes: la cronología del incario en la Historia de los Incas de Pedro Sarmiento de Gamboa (1572). Estudios Atacameños. Arqueología y Antropología Surandinas, 51, 153-175.

Grimson, A. (2011). Los limites de la cultura. Critica de las teorias de la identidad. Buenos Aires: Siglo Veintiuno Editores.

Guaman Poma, F. (1987). Nueva crónica y buen gobierno. Murra, J., Adorno, R. y Urioste, J. (Eds.). Madrid: Historia, 16 .

Hampe, T. (1986). Apuntes para una biografía del licenciado Polo de Ondegardo. Revista Histórica, XXXV, 81-115.

Hidalgo, J. (1986). Indian Society in Arica, Tarapaca and Atacama, 1750-1793, and its Response to the Rebellion of Tupac Amaru. Tesis doctoral. University of London, Londres.

Hidalgo, J., y Castro, N. (2014). El liderazgo étnico en Atacama, Altos de Arica, Tacna y Tarata. En Hidalgo, J. (Ed.). Historia Andina en Chile, vol. II. Politicas imperiales, dinámicas regionales y sociedades indigenas (pp. 319335). Santiago: Editorial Universitaria.

Honores, R. (2007). Los caciques y las pruebas: El uso de las testimoniales en las disputas por cacicazgos en la $\mathrm{Au}-$ diencia de Lima, 1550-1610. XI Jornadas Interescuelas/ Departamentos de Historia. Departamento de Historia, Facultad de Filosofía y Letras. Universidad de Tucumán, San Miguel de Tucumán. Recuperado de https://www. aacademica.org/000-108/924 
Honores, R. (2010). Colonial Legal Polyphony: Caciques and the Construction of Legal Arguments in the Andes, 1550-1640. Working Paper, 10-11, International Seminar on the History of the Atlantic World, 1500-1825. Recuperado de https://www.academia.edu/32255913/_ Colonial_Legal_Polyphony_and_Legal_Arguments_1550-1640_

Horta, H. (2008). Insignias para la frente de los nobles incas: una aproximación etnohistórica-arqueológica al principio de la dualidad. En González, P. y Bray, T. (Eds.). Lenguajes visuales de los Incas (pp. 71-89). Oxford: BAR International Series 1848.

Inch, M. (2010). El mundo letrado de los lupacas. Alfabetización y primeras letras a fines del siglo XVI e inicios del XVII. En Medinacelli, X. e Inch, M. (Coords.). Pleitos y riqueza. Los caciques andinos en Potosi del siglo XVII: transcripción y estudios del expediente de don Diego Chambilla contra los bienes de su administrador (pp. 507-527). Sucre: Ediciones Archivo y Biblioteca Nacionales de Bolivia.

Jurado, C. (2014). "Descendientes de los primeros". Las probanzas de méritos y servicios y la genealogía cacical. Audiencia de Charcas, 1574 - 1719. Revistas de Indias, LXXIV (261), 387-422.

Konetzke, R. (1962). Colección de documentos para la historia de la formación social de Hispanoamérica, 1493-1810. Tomo III. Madrid: Consejo Superior de Investigaciones.

Lamana, G. (2012). Pensamiento colonial critico. Textos y actos de Polo de Ondegardo. Lamana, G. (Ed.). Estudio biográfico de Teodoro Hampe. Lima - Cuzco: Instituto Francés de Estudios Andinos - Centro de Estudios Regionales Andinos Bartolomé de Las Casas.

Levillier, R. (1919). El licenciado Matienzo (oidor de la Audiencia de Charcas 1561-1579), inspirador de la segunda fundación de Buenos Aires. Madrid: Imprenta de Pueyo.

Levillier, R. (1922). La Audiencia de Charcas. Correspondencia de presidentes y oidores. Documentos del Archivo de Indias. Madrid: Imprenta de Pueyo.

López, C. (2012). Alianzas familiares. Élite, género y negocios en La Paz, Charcas, siglo XVII. La Paz: Plural Editores ABNB.
Luque, M. (2004). "Tan príncipes e infantes como los de Castilla”. Análisis histórico-jurídico de la nobleza indiana de origen prehispánico. Anales del Museo de América, $12,9-34$.

Marchal, G. (2001). De la mémoire communicative à la mémoire culturelle. Le passé dans les témoignages d'Arezzo et de Sienne (1177-1180). Annales. Histoire, Sciences Sociales, 56, 3, 563-589.

Martínez, J. (1995). Autoridades en los Andes: los atributos del señor. Lima: Pontificia Universidad Católica del Perú, Fondo Editorial.

Matienzo, J. de (1967 [1567]). Gobierno del Perú (1567). Edición y estudio preliminar de Guillermo Lohmann Villena. París - Lima: Institut Français d’Études Andines.

Medinacelli, X. (2008). Potosí y La Plata: la experiencia de la ciudad andina (siglos XVI y XVIII). En Eichmann, A., e Inch, M. (Eds.). La construcción de lo urbano en Potosí y La Plata, siglos XVI y XVII (pp. 3-145). Sucre: Ministerio de Cultura de España - ABNB.

Medinacelli, X., e Inch, M. (Coords.). (2010). Pleitos y riquezas. Los caciques andinos en Potosi del siglo XVII. Sucre: Ediciones Archivo y Biblioteca Nacionales de Bolivia.

Memorias (1859). Memorias de los Virreyes. Tomo IV. Lima: Librería Central de Felipe Bailly.

Menéndez Pidal, F. (2006). El linaje y sus signos de identidad. En la España medieval, Número Extra 1, 12-28.

Merluzzi, M. (2008). Memoria histórica y gobierno imperial. Las informaciones sobre el origen y descendencia del gobierno de los incas. Rosario: Prohistoria Ediciones.

Monterroso, G. (1591 [1563]). Pratica civil y criminal, y instrvcion de escrivanos: Diuidida en nueue Tratados. Madrid: Pedro Madrigal.

Morong, G. (2013). De la natural inclinación y condición de los indios: el oidor Matienzo y su proyecto de gobernabilidad para el Perú Virreinal, 1567. Diálogo Andino, $42,17-30$.

Morong, G. (2016). Saberes hegemónicos y dominio colonial. Los indios en el Gobierno del Perú de Juan de Matienzo (1567). Rosario: Prohistoria Ediciones. 
Morrone, A. (2013). Estrategias estatales y liderazgo étnico en el corregimiento de Pacajes (1538-1620). En Presta, A. M. (Ed.). Aportes multidisciplinarios al estudio de los colectivos étnicos surandinos. Reflexiones sobre QaraqaraCharcas tres años después (pp. 343-372). La Paz: Plural Editores - IFEA.

Mumford, J. (2011). Francisco de Toledo, admirador y émulo de la "tiranía” inca. Histórica, XXXV(2), 45-67.

Murra, J. (2002 [1998]). El doctor Barros de San Millán. Defensor de los "señores naturales" de los Andes. En Murra, J. El mundo andino. Población, medio ambientes y economía (pp. 426-438). Lima: Pontificia Universidad Católica del Perú - Instituto de Estudios Peruanos.

O’Phelan, S. (1995). La gran rebelión en los Andes: de Tupac Amaru a Tupac Catari. Cuzco: Centro de Estudios Regionales Andinos Bartolomé de Las Casas.

O'Phelan, S. 1(999). Repensando el Movimiento Nacional Inca del siglo XVIII. En O'Phelan, S. (Coord.). El Perú en el siglo XVIII. La Era Borbónica (pp. 263-277). Lima: Instituto Riva-Agüero - Pontificia Universidad Católica del Perú.

Platt, T. et al. (2011). Qaraqara-Charka. Mallku, Inka y Rey en la provincia de Charcas (siglos XV-XVII). Historia antropológica de una confederación aymara. La Paz: IFEA - Plural Editores - University of St. Andrews - University of London.

Platt, T. (2015). Refounding the house. Time, Politics, and Metallogenesis in a Colonial Aymara of Arms. En Aveni, A. (Ed.). The measure and meaning of time in Mesoamerica and the Andes (pp. 239-273). Washington: Dumbarton Oaks.

Platt, T. (2018). "Un ceque de la muerte”. Milagros, memoria y ruptura en San Bartolomé de Carata, Macha. Siglos XVI-XXI. En Muñoz, M. (Ed.). Interpretando huellas. Arqueología, Etnohistoria y Etnografia de los Andes y sus Tierras Bajas (pp. 619-656). Cochabamba: Grupo Editorial Kipus.

Polo de Ondegardo, J. (1916). Relación de los fundamentos acerca de 1 notable daño que resulta de no guardar a los indios sus fueros. Junio 26 de 1571. Informaciones acerca de la religión y gobierno de los incas (pp. 45-127). Colección de Libros y Documentos referentes a la historia del
Perú. Tomo III. Lima: Imprenta San Marti y Cía.

Presta, A. M. (2014). Encomienda, familia y negocios en Charcas colonial. Los encomenderos de La Plata, 15501600. Sucre: ABNB.

Puente, J. (2017). Incas pecheros y caballeros hidalgos: la desintegración del orden incaico y la génesis de la nobleza incaica colonial en el Cuzco del siglo XVI. Revista Andina, 54, 9-63.

Quispe-Agnoli, R. (2016). Nobles de Papel: Identidades oscilantes y genealogias borrosas en los descendientes de la realeza Inca. Madrid: Iberoamericana - Vervuert.

RAE (1726-1739). Diccionario de autoridades. Madrid: Joaquí Ibarra Impresor. Recuperado de http:// www.rae.es/recursos/diccionarios/diccionarios-anteriores-1726-1996/diccionario-de-autoridades

Ramírez del Águila, P. (2017). Noticias politicas de Indias y relación descriptiva de la ciudad de La Plata, metrópoli de las provincias de los Charcas. Benjamín, N., Sierra, M., Pacheco, M., y Gantier, B. (Eds.). Sucre: Ciencia Editores.

Ramos, G. (2005). Los símbolos de poder inca durante el virreinato. En Cummins, T. et al. Los incas, reyes del Perú (pp. 43-65). Lima: Banco de Crédito del Perú.

Ramos, G. (2016). El rastro de la discriminación. Litigios y probanzas de caciques en el Perú colonial temprano. Fronteras de la Historia, 21(1), 66-90.

Ramos Gavilán, A. (1976 [1621]). Historia de Nuestra Señora de Copacabana. La Paz: Academia Boliviana de la Historia.

Real Audiencia de La Plata (2007). Acuerdos de la Real Audiencia de La Plata 1576-1587. Vol. 3. Sucre: Corte Suprema de Justicia - Agencia Española de Cooperación Internacional - ABNB.

Río, M. del (2009). De sacerdotes del tawantinsuyu a cófrades coloniales: Nuevas evidencias sobre los Acustupa y Viracocha Inga de Copacabana. Revista Andina, 49, 9-69.

Rojas, J. de (2010). Cambiar para que yo no cambie. La nobleza indigena en la Nueva España. Buenos Aires: Editorial SB. 
Ruiz, E. (2006). La carta ejecutoria de hidalguía: un espacio gráfico privilegiado. En la España medieval, Número Extra 1, 251-276.

Solórzano, J. de (1648). Politica Indiana. Madrid: Diego Díaz de la Carrera Impresor.

Toledo, F. de (1986). Disposiciones gubernativas para el virreinato del Perú, 1575-1580, vol. 2. Introducción de Guillermo Lohmann Villena y transcripción de María Justina Saravia Viejo. Escuela de Estudios Hispanoamericanos, CSIC, Sevilla.

Villena, E. (2004). El arte de la medalla en la España Ilustrada. Madrid: Centro Cultural Conde Duque - Concejalía de Las Artes del Ayuntamiento de Madrid - Fundación Caja.

Walker, C. (2015). La rebelión de Tupac Amaru. Lima: Instituto de Estudios Peruanos.

Weber, M. (2014). Economía y sociedad. México: Fondo de Cultura Económica.
Yannakakis, Y. (2013). Indigenous People and Legal Culture in Spanish America. History Compass, 11(11), 931947. Recuperado de http://onlinelibrary.wiley.com/ doi/10.1111/hic3.12096/epdf

Zighelboim, A. (2010). Un inca cuzqueño en la corte de Fernando VI: Estrategias personales y colectivas de las elites indias y mestizas hacia 1750. Histórica, XXXIV(2), 7-62.

Zuñiga, J. P. (1999). La voix du sang. Du métis à l'idée de métissage en Amérique espagnole. En Annales, 54(2), 425-452.

\section{Fuentes documentales}

Archivo General de Indias (AGI)

Archivo y Biblioteca Diocesanos de Sucre (ABNB)

Archivo General de la Nación Argentina (AGNA) 